\title{
Epitaxial Stabilization between Intermetallic and Carbide Domains in the Structures of $\mathrm{Mn}_{16} \mathrm{SiC}_{4}$ and $\mathrm{Mn}_{17} \mathrm{Si}_{2} \mathrm{C}_{4}$
}

Rie T. Fredrickson, Yiming Guo, and Daniel C. Fredrickson*

Department of Chemistry, University of Wisconsin-Madison, 1101 University Avenue, Madison, WI 57306, United States

*E-mail: danny@chem.wisc.edu

\section{Supporting Information}

\section{S1. Crystallographic Tables for $\mathrm{Mn}_{16} \mathrm{SiC}_{4}$ and $\mathrm{Mn}_{17} \mathrm{Si}_{2} \mathrm{C}_{4}$}

Table S1. Crystal Data for $\mathrm{Mn}_{16} \mathrm{SiC}_{4}$ and $\mathrm{Mn}_{17} \mathrm{Si}_{2} \mathrm{C}_{4}$

\begin{tabular}{|c|c|c|}
\hline Chemical formula & $\mathrm{Mn}_{16} \mathrm{SiC}_{4}$ & $\mathrm{Mn}_{17} \mathrm{Si}_{2} \mathrm{C}_{4}$ \\
\hline WDS composition & $\mathrm{Mn}_{16} \mathrm{Si}_{0.917(10)} \mathrm{C}_{4.14(6)}$ & $\mathrm{Mn}_{17} \mathrm{Si}_{1.781(14)} \mathrm{C}_{4.16(9)}$ \\
\hline Space group & $C 2 / m$ & $P 2_{1} / m$ \\
\hline Unit cell $a[\AA]$ & $10.280(3)$ & $6.4114(9)$ \\
\hline$b[\AA]$ & $7.7913(19)$ & $7.6648(5)$ \\
\hline$c[\AA]$ & $6.3715(16)$ & $10.4946(16)$ \\
\hline$\beta\left[^{\circ}\right]$ & $119.12(3)$ & $106.247(13)$ \\
\hline Cell volume & $445.8(2)$ & $495.13(11)$ \\
\hline $\mathrm{Z}$ & 2 & 2 \\
\hline Pearson symbol & $m C 42$ & $m P 46$ \\
\hline Cryst. dimensions $\left[\mathrm{mm}^{3}\right]$ & $0.08 \times 0.04 \times 0.02$ & $0.11 \times 0.07 \times 0.02$ \\
\hline Crystal color & Metallic black & Metallic black \\
\hline Crystal habit & Plate & Plate \\
\hline Data collection temp. & RT & RT \\
\hline Radiation source, $\lambda[\AA]$ & $\mathrm{Mo}, \mathrm{Ka}[0.7107]$ & $\mathrm{Mo}, \mathrm{Ka}[0.7107]$ \\
\hline Absorption coefficient & $21.837 \mathrm{~mm}^{-1}$ & $21.007 \mathrm{~mm}^{-1}$ \\
\hline Absorption correction & Analytical & Multi-scan \\
\hline $\mathrm{Min} / \mathrm{max}$ transmission & $0.363,0.718$ & $0.338,1.000$ \\
\hline$\theta_{\min }, \theta_{\max }$ & $3.46,27.34$ & $3.31,28.79$ \\
\hline Number of reflections & 2132 & 4268 \\
\hline Unique refl. $[\mathrm{I}>3 \sigma(\mathrm{I})$, all $]$ & 437,567 & 950,1250 \\
\hline Refinement method & $\mathrm{F}^{2}$ & $\mathrm{~F}^{2}$ \\
\hline $\mathrm{R}_{\mathrm{int}}[\mathrm{I}>3 \sigma(\mathrm{I})$, all $]$ & $4.47,4.83$ & $4.84,5.10$ \\
\hline Number of parameters & 55 & 55 \\
\hline $\mathrm{R}[\mathrm{I}>3 \sigma(\mathrm{I})], \mathrm{R}_{\mathrm{w}}[\mathrm{I}>3 \sigma(\mathrm{I})]$ & $0.0265,0.0466$ & $0.0329,0.0505$ \\
\hline $\mathrm{R}(\mathrm{all}), \mathrm{R}_{\mathrm{w}}(\mathrm{all})$ & $0.0459,0.0536$ & $0.0338,0.0383$ \\
\hline $\mathrm{S}[\mathrm{I}>3 \sigma(\mathrm{I})], \mathrm{S}($ all $)$ & $1.12,1.11$ & $1.19,1.16$ \\
\hline$\Delta \rho_{\max }, \Delta \rho_{\min }\left(\mathrm{e}^{-} / \AA^{-3}\right)$ & $1.08,-1.04$ & $1.17,-1.24$ \\
\hline
\end{tabular}


Table S2. Refined atomic coordinates of $\mathrm{Mn}_{16} \mathrm{SiC}_{4}$

\begin{tabular}{lcccccc}
\hline & Wyckoff & & & & & \\
Site & position & $x$ & $y$ & $z$ & $U_{\text {equiv }}$ & Occupancy \\
\hline Mn1 & $8 j$ & $0.38625(8)$ & $0.23114(12)$ & $0.04660(17)$ & $0.0061(4)$ & 1 \\
Mn2 & $8 j$ & $0.35572(9)$ & $0.34097(11)$ & $0.62782(18)$ & $0.0056(4)$ & 1 \\
Mn3 & $4 h$ & 0.5 & $0.16790(16)$ & 0.5 & $0.0065(5)$ & 1 \\
Mn4 & $4 i$ & $0.38147(13)$ & 0.5 & $0.2834(3)$ & $0.0072(5)$ & 1 \\
Mn5 & $4 i$ & $0.21636(12)$ & 0.5 & $0.7987(2)$ & $0.0064(5)$ & 1 \\
Mn6 & $4 i$ & $0.60728(13)$ & 0 & $0.2513(3)$ & $0.0091(5)$ & 1 \\
Si1 & $2 a$ & 0.5 & 0.5 & 0 & $0.0045(12)$ & 1 \\
C1 & $8 j$ & $0.2935(5)$ & $0.2643(8)$ & $0.2856(11)$ & $0.008(2)$ & 1 \\
\hline
\end{tabular}

Table S3. Refined anisotropic atomic displacement parameters for $\mathrm{Mn}_{16} \mathrm{SiC}_{\mathbf{4}}$

\begin{tabular}{ccccccc}
\hline Site & $U_{11}$ & $U_{22}$ & $U_{33}$ & $U_{12}$ & $U_{13}$ & $U_{23}$ \\
\hline Mn1 & $0.0048(4)$ & $0.0081(5)$ & $0.0036(5)$ & $-0.0005(3)$ & $0.0007(4)$ & $0.0001(4)$ \\
Mn2 & $0.0048(4)$ & $0.0063(5)$ & $0.0042(5)$ & $-0.0008(3)$ & $0.0011(4)$ & $-0.0004(4)$ \\
Mn3 & $0.0057(6)$ & $0.0071(6)$ & $0.0057(7)$ & 0 & $0.0020(5)$ & 0 \\
Mn4 & $0.0100(6)$ & $0.0057(6)$ & $0.0068(7)$ & 0 & $0.0048(5)$ & 0 \\
Mn5 & $0.0056(6)$ & $0.0051(7)$ & $0.0067(7)$ & 0 & $0.0016(5)$ & 0 \\
Mn6 & $0.0099(6)$ & $0.0074(6)$ & $0.0086(8)$ & 0 & $0.0036(6)$ & 0 \\
Si1 & $0.0041(14)$ & $0.0052(16)$ & $0.0028(17)$ & 0 & $0.0005(13)$ & 0 \\
C1 & $0.005(3)$ & $0.013(3)$ & $0.002(3)$ & $0.002(2)$ & $0.000(2)$ & $0.001(3)$ \\
\hline
\end{tabular}


Table S4. Selected interatomic distances in $\mathrm{Mn}_{16} \mathrm{SiC}_{4}$

\begin{tabular}{|c|c|c|c|c|c|}
\hline \multirow{2}{*}{ Mn1 } & ite & \multirow{2}{*}{$\frac{\text { Distance }(\AA)}{2.6785(18)}$} & & \multirow{2}{*}{$\begin{array}{l}\text { Site } \\
\text { Mn6 }\end{array}$} & \multirow{2}{*}{$\frac{\text { Distance }(\AA)}{2.802(2)}$} \\
\hline & $\mathrm{Mn} 1$ & & & & \\
\hline & Mn1 & $2.582(2)$ & & Mn6 & $2.7406(16)$ \\
\hline & $\mathrm{Mn} 2$ & $2.671(2)$ & $\mathrm{Mn} 2$ & Sil & $2.4362(18)$ \\
\hline & $\mathrm{Mn} 2$ & $2.591(2)$ & & $\mathrm{C} 1$ & $2.040(7)$ \\
\hline & Mn3 & $2.582(2)$ & & $\mathrm{C} 1$ & $2.038(7)$ \\
\hline & Mn4 & $2.5958(17)$ & Mn3 & $\mathrm{Mn} 3$ & $2.616(2)$ \\
\hline & Mn5 & $2.6922(16)$ & & $\mathrm{Mn} 5$ & $2.482(2)$ \\
\hline & Mn5 & $2.5177(18)$ & & Mn5 & $2.482(2)$ \\
\hline & Mn6 & $2.6874(18)$ & & Mn6 $(\times 2)$ & $2.6722(19)$ \\
\hline & Mn6 & $2.6405(19)$ & & $\mathrm{C} 1(\times 2)$ & $2.029(5)$ \\
\hline & Si1 & $2.4863(13)$ & $\mathrm{Mn} 4$ & $\mathrm{Mn} 4$ & $2.648(3)$ \\
\hline & $\mathrm{C} 1$ & $2.170(8)$ & & Mn5 & $2.704(3)$ \\
\hline & $\mathrm{C} 1$ & $2.022(5)$ & & Mn6 & $2.725(3)$ \\
\hline $\mathrm{Mn} 2$ & $\mathrm{Mn} 2$ & $2.4374(18)$ & & Sil & $2.624(2)$ \\
\hline & $\mathrm{Mn} 2$ & $2.4781(17)$ & & $\mathrm{C} 1(\times 2)$ & $2.050(6)$ \\
\hline & Mn3 & $2.4202(15)$ & Mn5 & Sil & $2.551(2)$ \\
\hline & Mn4 & $2.643(2)$ & & $\mathrm{C} 1(\times 2)$ & $2.118(6)$ \\
\hline & $\mathrm{Mn} 4$ & $2.769(2)$ & Mn6 & Mn6 & $2.871(3)$ \\
\hline & Mn5 & $2.508(2)$ & & & \\
\hline
\end{tabular}


Table S5. Refined atomic coordinates for $\mathrm{Mn}_{17} \mathrm{Si}_{2} \mathrm{C}_{4}$

\begin{tabular}{lcccccc}
\hline \multicolumn{1}{c}{ Site } & Wyckoff & & & & & \\
position & $x$ & $y$ & $U_{\text {equiv }}$ & Occupancy \\
Mn1 & $2 e$ & $0.7288(2)$ & 0.25 & $0.27717(14)$ & $0.0039(4)$ & 1 \\
Mn3 & $4 f$ & $0.50432(15)$ & $0.08920(12)$ & $0.40516(10)$ & $0.0041(3)$ & 1 \\
Mn4 & $4 f$ & $0.81647(16)$ & $0.55463(12)$ & $0.01027(11)$ & $0.0051(3)$ & 1 \\
Mn5 & $2 e$ & $0.9552(2)$ & 0.25 & $0.12787(15)$ & $0.0044(5)$ & 1 \\
Mn6 & $4 f$ & $0.15300(16)$ & $-0.02056(12)$ & $0.24946(10)$ & $0.0051(3)$ & 1 \\
Mn7 & $2 e$ & $0.87034(16)$ & $0.52237(12)$ & $0.38886(10)$ & $0.0047(3)$ & 1 \\
Mn8 & $2 e$ & $1.1352(2)$ & 0.25 & $0.40676(15)$ & $0.0053(5)$ & 1 \\
Mn9 & $4 f$ & $0.52085(16)$ & $0.53690(13)$ & $0.17361(11)$ & $0.0060(3)$ & 1 \\
Mn10 & $2 e$ & $0.5435(2)$ & 0.25 & $0.02501(15)$ & $0.0069(5)$ & 1 \\
Mn11 & $2 e$ & $0.8425(2)$ & 0.75 & $0.21213(15)$ & $0.0059(5)$ & 1 \\
Mn12 & $2 e$ & $0.5201(2)$ & 0.75 & $0.36518(16)$ & $0.0081(5)$ & 1 \\
Si1 & $2 e$ & $0.1876(4)$ & -0.25 & $0.1068(3)$ & $0.0031(8)$ & 1 \\
Si2 & $2 e$ & $1.3341(4)$ & 0.25 & $0.1964(3)$ & $0.0046(8)$ & 1 \\
C1 & $4 f$ & $0.7663(11)$ & $0.5025(8)$ & $0.5511(7)$ & $0.008(2)$ & 1 \\
C2 & $4 f$ & $0.8309(10)$ & $0.0350(8)$ & $0.1926(7)$ & $0.006(2)$ & 1 \\
\hline
\end{tabular}

Table S6. Refined anisotropic atomic displacement parameters for $\mathrm{Mn}_{17} \mathbf{S i}_{\mathbf{2}} \mathrm{C}_{\mathbf{4}}$

\begin{tabular}{ccccccc}
\hline Site & $U_{11}$ & $U_{22}$ & $U_{33}$ & $U_{12}$ & $U_{13}$ & $U_{23}$ \\
\hline Mn1 & $0.0028(7)$ & $0.0046(6)$ & $0.0041(7)$ & 0 & $0.0007(5)$ & 0 \\
Mn2 & $0.0030(5)$ & $0.0043(5)$ & $0.0051(5)$ & $-0.0004(4)$ & $0.0011(4)$ & $0.0010(4)$ \\
Mn3 & $0.0044(5)$ & $0.0066(5)$ & $0.0041(5)$ & $0.0006(4)$ & $0.0007(4)$ & $0.0007(4)$ \\
Mn4 & $0.0028(7)$ & $0.0053(7)$ & $0.0048(8)$ & 0 & $0.0007(5)$ & 0 \\
Mn5 & $0.0033(5)$ & $0.0059(5)$ & $0.0057(6)$ & $-0.0008(4)$ & $0.0008(4)$ & $-0.0011(4)$ \\
Mn6 & $0.0039(5)$ & $0.0064(5)$ & $0.0037(5)$ & $-0.0015(4)$ & $0.0010(4)$ & $-0.0005(4)$ \\
Mn7 & $0.0030(8)$ & $0.0035(6)$ & $0.0089(8)$ & 0 & $-0.0004(6)$ & 0 \\
Mn8 & $0.0040(7)$ & $0.0045(7)$ & $0.0079(8)$ & 0 & $0.0025(6)$ & 0 \\
Mn9 & $0.0036(5)$ & $0.0079(5)$ & $0.0062(6)$ & $0.0006(4)$ & $0.0009(4)$ & $0.0007(4)$ \\
Mn10 & $0.0045(8)$ & $0.0101(7)$ & $0.0061(8)$ & 0 & $0.0014(6)$ & 0 \\
Mn11 & $0.0050(8)$ & $0.0045(6)$ & $0.0083(8)$ & 0 & $0.0022(6)$ & 0 \\
Mn12 & $0.0097(8)$ & $0.0062(7)$ & $0.0093(8)$ & 0 & $0.0040(6)$ & 0 \\
Si1 & $0.0043(13)$ & $0.0022(11)$ & $0.0029(13)$ & 0 & $0.0011(10)$ & 0 \\
Si2 & $0.0011(13)$ & $0.0068(12)$ & $0.0058(14)$ & 0 & $0.0007(10)$ & 0 \\
C1 & $0.004(3)$ & $0.006(3)$ & $0.016(4)$ & $0.003(3)$ & $0.003(3)$ & $0.002(3)$ \\
C2 & $0.005(3)$ & $0.006(3)$ & $0.006(4)$ & $-0.002(3)$ & $0.000(3)$ & $0.000(3)$ \\
\hline
\end{tabular}


Table S7. Selected interatomic distances in $\mathbf{M n}_{17} \mathbf{S i}_{2} \mathbf{C}_{\mathbf{4}}$

\begin{tabular}{|c|c|c|c|c|c|}
\hline \multirow{2}{*}{ Mn1 } & \multirow{2}{*}{$\begin{array}{l}\text { Site } \\
\text { Mn2 }(\times 2)\end{array}$} & \multirow{2}{*}{$\frac{\text { Distance }(\AA)}{2.5449(19)}$} & \multicolumn{2}{|c|}{ Site } & \multirow{2}{*}{$\frac{\text { Distance }(\AA)}{2.029(7)}$} \\
\hline & & & & $\mathrm{C} 2(\times 2)$ & \\
\hline & Mn4 & $2.416(2)$ & Mn5 & Mn6 & $2.6283(18)$ \\
\hline & Mn6 (×2) & $2.4414(12)$ & & $\mathrm{Mn} 7$ & $2.7600(17)$ \\
\hline & Mn7 & $2.716(2)$ & & $\mathrm{Mn} 8$ & $2.6729(15)$ \\
\hline & $\mathrm{Mn} 8$ & $2.580(2)$ & & Mn9 & $2.6948(17)$ \\
\hline & $\operatorname{Mn} 9(\times 2)$ & $2.6427(12)$ & & Mn11 & $2.6025(15)$ \\
\hline & Mn10 & $2.580(2)$ & & Sil & $2.360(2)$ \\
\hline & Si2 & $2.434(3)$ & & $\mathrm{Si} 2$ & $2.514(2)$ \\
\hline & $\mathrm{C} 2(\times 2)$ & $2.063(7)$ & & $\mathrm{C} 1$ & $2.019(8)$ \\
\hline \multirow[t]{12}{*}{$\mathrm{Mn} 2$} & $\mathrm{Mn} 2$ & $2.4285(16)$ & & $\mathrm{C} 2$ & $2.028(6)$ \\
\hline & $\mathrm{Mn} 2$ & $2.4649(13)$ & Mn6 & Mn6 & $2.4806(16)$ \\
\hline & $\mathrm{Mn} 5$ & $2.5282(15)$ & & $\mathrm{Mn} 7$ & $2.7058(15)$ \\
\hline & Mn6 & $2.5480(16)$ & & $\mathrm{Mn} 7$ & $2.5020(14)$ \\
\hline & $\mathrm{Mn} 7$ & $2.5601(16)$ & & Mn8 & $2.6642(14)$ \\
\hline & Mn8 & $2.6727(18)$ & & Mn8 & $2.7728(17)$ \\
\hline & Mn9 & $2.6447(17)$ & & Mn9 & $2.7026(16)$ \\
\hline & Mn12 & $2.6400(10)$ & & Mn11 & $2.5161(16)$ \\
\hline & Mn12 & $2.750(2)$ & & Mn12 & 2.7993(17) \\
\hline & $\mathrm{Si} 2$ & $2.484(3)$ & & $\mathrm{C} 1$ & $2.000(8)$ \\
\hline & $\mathrm{C} 1$ & $2.027(8)$ & & $\mathrm{C} 1$ & $2.245(7)$ \\
\hline & $\mathrm{C} 1$ & $2.054(6)$ & & $\mathrm{C} 2$ & $2.051(7)$ \\
\hline \multirow[t]{11}{*}{ Mn3 } & Mn3 & $2.5632(17)$ & Mn7 & Mn8 & $2.703(2)$ \\
\hline & Mn4 & $2.6744(12)$ & & Mn11 & $2.771(2)$ \\
\hline & $\mathrm{Mn} 4$ & $2.7702(19)$ & & Mn12 & $2.714(2)$ \\
\hline & $\mathrm{Mn} 5$ & $2.8458(18)$ & & $\mathrm{C} 1(\times 2)$ & $1.995(6)$ \\
\hline & Mn5 & $2.8274(17)$ & Mn8 & Mn12 & $2.767(2)$ \\
\hline & Mn9 & $2.5609(15)$ & & $\mathrm{C} 1(\times 2)$ & $2.009(6)$ \\
\hline & Mn10 & $2.6884(17)$ & Mn9 & Mn10 & $2.7232(15)$ \\
\hline & Mn11 & $2.5614(18)$ & & Mn10 & $2.5888(17)$ \\
\hline & Sil & $2.6351(17)$ & & Mn11 & $2.5724(16)$ \\
\hline & Si2 & $2.590(2)$ & & Mn12 & $2.5914(18)$ \\
\hline & $\mathrm{C} 2$ & $2.011(7)$ & & Sil & $2.624(2)$ \\
\hline \multirow[t]{5}{*}{$\mathrm{Mn} 4$} & $\operatorname{Mn} 5(\times 2)$ & $2.5752(12)$ & & $\mathrm{Si} 2$ & $2.5469(18)$ \\
\hline & Mn8 & $2.830(2)$ & & $\mathrm{C} 2$ & $2.018(7)$ \\
\hline & Mn10 & $2.557(2)$ & Mn10 & Sil & $2.494(4)$ \\
\hline & Sil & $2.375(3)$ & & $\mathrm{Si} 2$ & $2.528(4)$ \\
\hline & Si2 & $2.333(3)$ & Mn11 & $\mathrm{C} 2(\times 2)$ & $2.193(6)$ \\
\hline
\end{tabular}




\section{S2. Expanded version of Figure 6 in main manuscript.}

The Crystal Structure of $\mathrm{Mn}_{17} \mathrm{Si}_{2} \mathrm{C}_{4}$

(a)

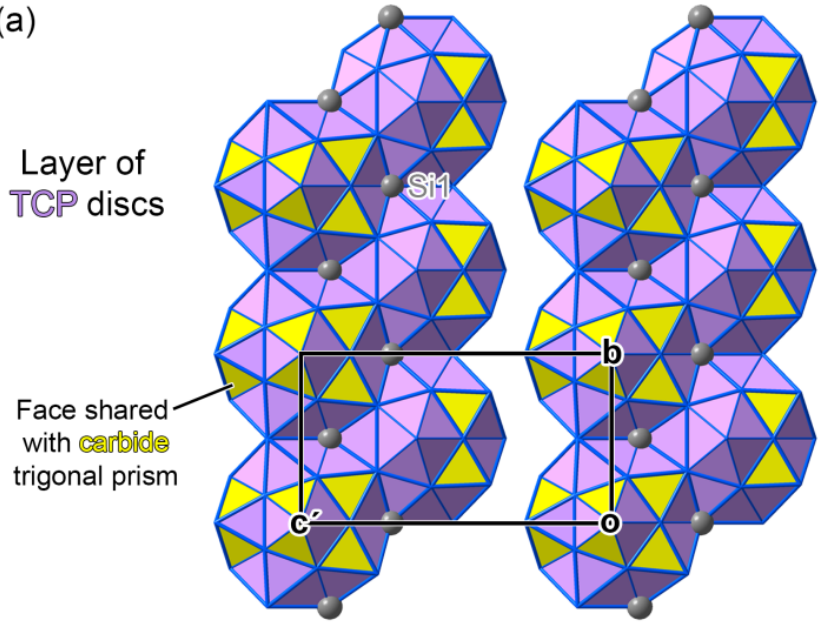

(b)

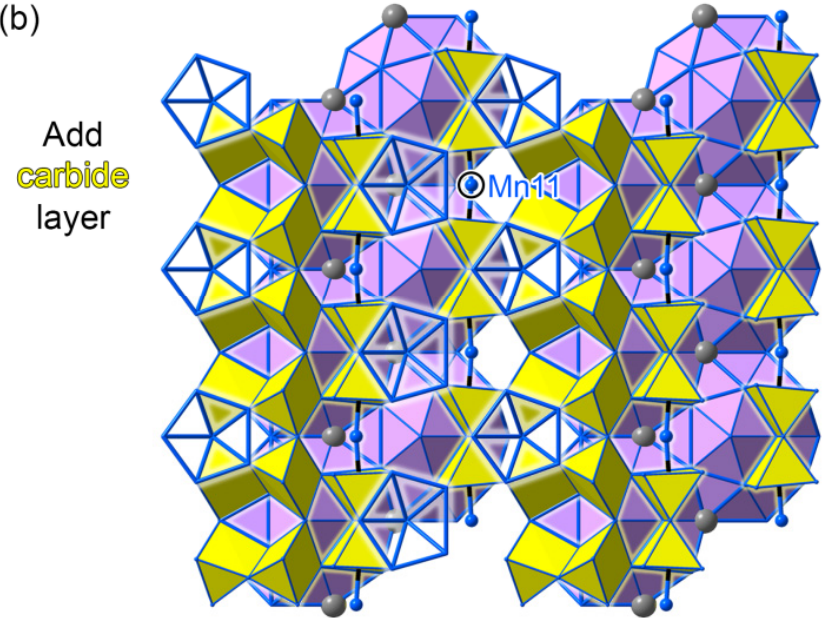

(c)

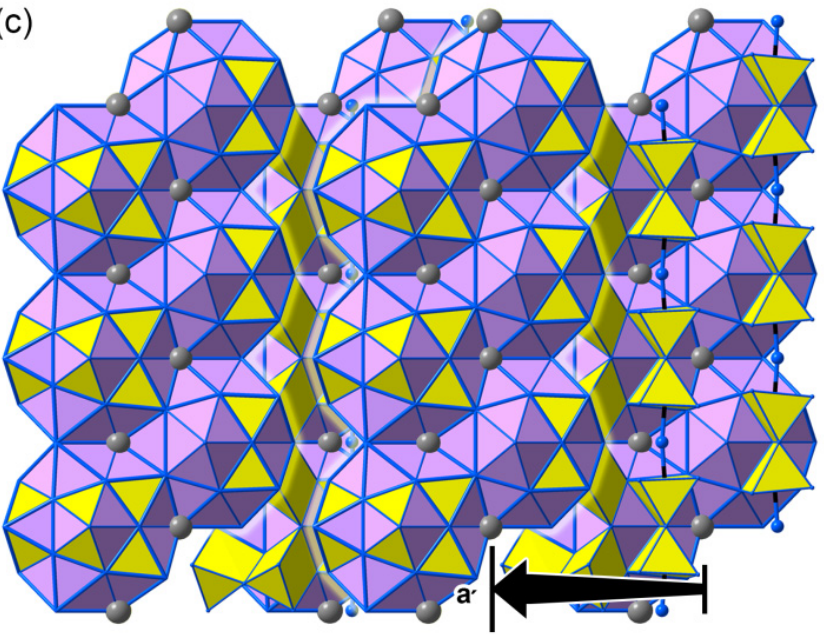

New TCP layer completes unit cell.
Figure S1. The crystal structure of $\mathrm{Mn}_{17} \mathrm{Si}_{2} \mathrm{C}_{4}$. As in $\mathrm{Mn}_{16} \mathrm{SiC}_{4}$, the structure can be constructed conceptually by beginning with (a) a layer of TCP motifs, (b) growing $\mathrm{C} @ \mathrm{Mn}_{6}$ trigonal prisms from a selection of triangular faces on the TCP layer, and (c) continuing the pattern through the addition of a new TCP layer translationally equivalent to the first. See text for a discussion of the significance of the $\mathrm{Sil}$ and Mn11 sites, as well as the choice of unit cell vectors. 


\section{S3. Powder X-ray diffraction data for $\mathrm{Mn}_{16} \mathrm{SiC}_{4}$ and $\mathrm{Mn}_{17} \mathrm{Si}_{2} \mathrm{C}_{4}$}

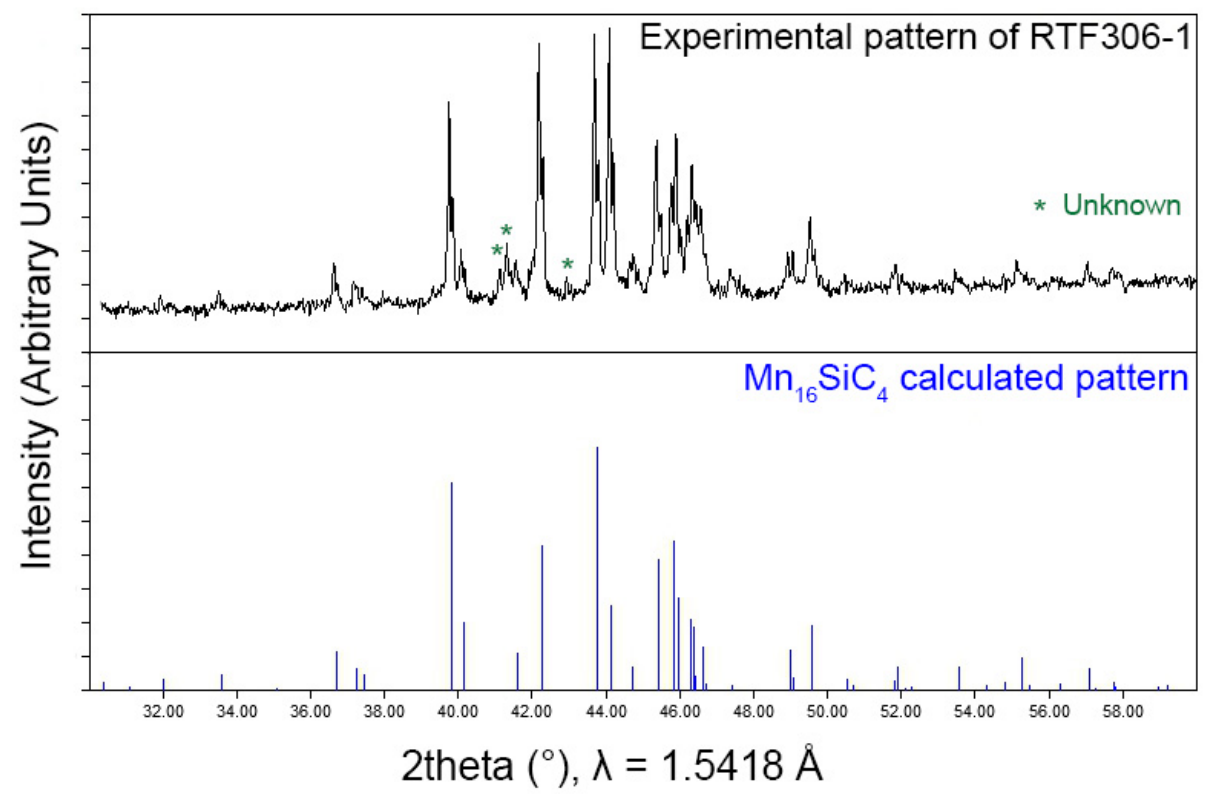

Figure S2. Powder X-ray diffraction of a sample containing $\mathrm{Mn}_{16} \mathrm{SiC}_{4}$ as the majority phase. The Calculated pattern from the refined crystal structure of $\mathrm{Mn}_{16} \mathrm{SiC}_{4}$ is shown for comparison.

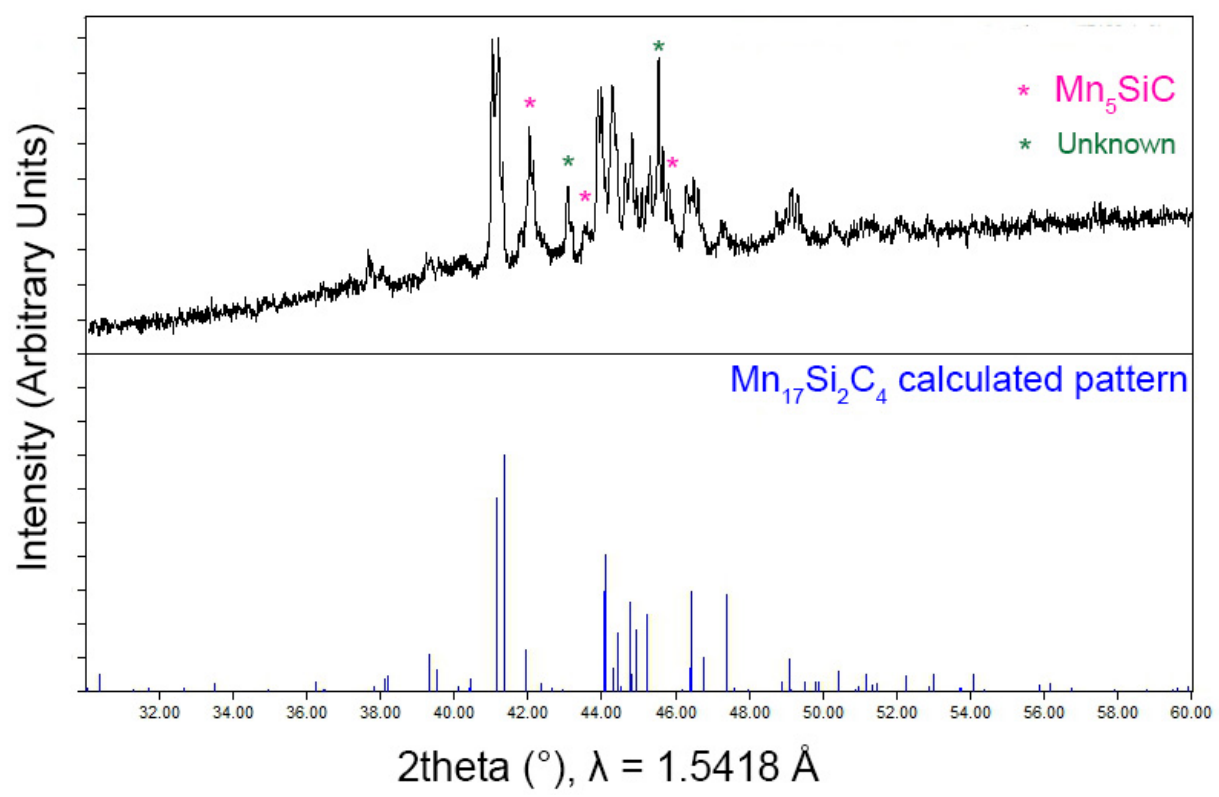

Figure S3. Powder X-ray diffraction data for a sample containing $\mathrm{Mn}_{17} \mathrm{Si}_{2} \mathrm{C}_{4}$ as the major phase, with the pattern calculated for the structural model refined from single crystal X-ray diffraction data shown for comparison. 


\section{S4. Sample preparation for EPMA measurements}

Each sample for EPMA measurements was prepared for by placing fragments inside an aluminum bullet filled with epoxy, which was heated at $70^{\circ} \mathrm{C}$ and then dried for 24 hours. Flat surfaces were then prepared by grinding the sample down with diamond paper, following by polishing with a 1 micron polycrystalline diamond suspension (Allied High Tech Products Inc.) spread onto a polishing wheel. The sample surfaces were uncoated, with sample grains surrounded by carbon paint.

\section{S5. Discussion of possible role of oxygen in formation of $\mathrm{Mn}_{16} \mathrm{SiC}_{4}$ and $\mathrm{Mn}_{17} \mathrm{Si}_{2} \mathrm{C}_{4}$}

From X-ray diffraction data alone, it is difficult to rule out the possibility of some oxygen impurities substituting on the carbon sites in $\mathrm{Mn}_{16} \mathrm{SiC}_{4}$ or $\mathrm{Mn}_{17} \mathrm{Si}_{2} \mathrm{C}_{4}$. However, the affinities of manganese for oxygen and carbon appear to have very different structural manifestations, which make such substitution seem unlikely. While $\mathrm{C}$ exhibits a high solubility in elemental $\mathrm{Mn},{ }^{1}$ the reactivity of $\mathrm{O}$ with $\mathrm{Mn}$ is expressed in the high stability of $\mathrm{MnO}$; oxygen has virtually no solubility in $\mathrm{Mn}^{2}$ and no more $\mathrm{Mn}$-rich oxides than $\mathrm{MnO}$ appear to exist. ${ }^{3}$ In addition, a search of common structure types containing trigonal prismatic coordination environments (NiAs, $\mathrm{FeB}, \mathrm{TlI}, \mathrm{Fe}_{3} \mathrm{C}, \mathrm{AlB}_{2}$, and $\mathrm{Cr}_{5} \mathrm{~B}_{3}$ ) in the Inorganic Crystal Structure Database (ICSD) ${ }^{4}$ reveals that $\mathrm{O}$ is rarely observed to occupy trigonal prismatic coordination polyhedra, as offered by the $\mathrm{Mn}_{16} \mathrm{SiC}_{4}$ and $\mathrm{Mn}_{17} \mathrm{Si}_{2} \mathrm{C}_{4}$ structures. These considerations are in-line with the electron microprobe data showing no appreciable oxygen content in the phases.

\section{S6. Magnetization data}

Before using electronic structure calculations to investigate the origins of the $\mathrm{Mn}_{16} \mathrm{SiC}_{4}$ and $\mathrm{Mn}_{17} \mathrm{Si}_{2} \mathrm{C}_{4}$ structures, it is necessary to ascertain to what extent magnetic ordering may be present in these $3 \mathrm{~d}$ metalrich compounds through magnetic properties measurements. Indeed, the nearby phase $\mathrm{Mn}_{5} \mathrm{SiC}$ in the $\mathrm{Mn}-\mathrm{Si}$-C system has been shown in earlier investigations to undergo ferromagnetic ordering below ca. $280 \mathrm{~K}$, and more complex ordering at lower temperatures: at around $50 \mathrm{~K}, \mathrm{Mn}_{5} \mathrm{SiC}$ exhibits a $15 \%$ drop in magnetic susceptibility, which has been attributed to a combination of helical and antiferromagnetic alignments of the spins. ${ }^{5}$

As is described in the synthetic results (Section 3.2), obtaining phase-pure samples has thus far been difficult using our synthetic procedures. $\mathrm{Mn}_{16} \mathrm{SiC}_{4}$ and $\mathrm{Mn}_{17} \mathrm{Si}_{2} \mathrm{C}_{4}$ tend to form with some component of $\mathrm{Mn}_{5} \mathrm{SiC}$ and smaller quantities of unidentified impurities. The presence of secondary phases makes an unambiguous characterization of the physical properties of the target compounds difficult. However, as will be seen below, a number of conclusions can still be reached about the magnetic behavior of these phases, particularly about the relative strengths of the magnetic moments of the $\mathrm{Mn}$ atoms of these phases compared to those in $\mathrm{Mn}_{5} \mathrm{SiC}$.

In our magnetization measurements, zero field-cooled and field-cooled magnetization scans were measured in an external field of 1000 Oe within the temperature range 6-350 K. Hysteresis curves were recorded at temperatures of $6 \mathrm{~K}$ and $300 \mathrm{~K}$ in the field range of at least $\pm 2.5 \mathrm{~T}$.

In Figure S4, we present the resulting plots of the magnetization as a function of temperature and applied field for samples in which $\mathrm{Mn}_{5} \mathrm{SiC}, \mathrm{Mn}_{16} \mathrm{SiC}_{4}$, or $\mathrm{Mn}_{17} \mathrm{Si}_{2} \mathrm{C}_{4}$ appear as the major phase. The magnetic properties measured for $\mathrm{Mn}_{5} \mathrm{SiC}$ (Figure S4a) confirm the trends observed previously for this 
phase. In the magnetization vs. temperature measurements (left panel), a large jump from nearly 0 to $\sim 0.15 \mu_{\mathrm{B}} / \mathrm{Mn}$ atom occurs below $290 \mathrm{~K}$. The magnetization continues to rise at lower temperatures, until it peaks at about $80 \mathrm{~K}$, after which it falls by about $15 \%$ relative to its maximum. These features are consistent with a ferromagnetic transition at ca. $290 \mathrm{~K}$ followed by the onset of more complex ordering below about $80 \mathrm{~K}$.

The field dependence of the sample magnetization is presented in the right panel of Figure S4a at $20 \mathrm{~K}$ (black) and $150 \mathrm{~K}$ (blue). The curves at both temperatures show a sharp climb from zero at $\mathrm{H}=0 \mathrm{~T}$ to nearly $\pm 0.2 \mu_{\mathrm{B}} / \mathrm{Mn}$ atom at small positive or negative values of $\mathrm{H}$. No hysteresis is evident, suggesting that the net ferromagnetic ordering in $\mathrm{Mn}_{5} \mathrm{SiC}$ is of a very soft nature.

The corresponding data for the $\mathrm{Mn}_{16} \mathrm{SiC}_{4}$ and $\mathrm{Mn}_{17} \mathrm{Si}_{2} \mathrm{C}_{4}$ sample (Figures $\mathrm{S} 4 \mathrm{~b}$ and $\mathrm{S} 4 \mathrm{c}$, respectively) show qualitatively similar behavior. For both samples, the onset of a ferromagnetic behavior occurs just below $300 \mathrm{~K}$, grows until a little below $100 \mathrm{~K}$, and then sharply drops. However, there is a major difference: the magnitudes of the magnetization are of quite different scales, with the measured moments being 10 to 20 times smaller than those measured for $\mathrm{Mn}_{5} \mathrm{SiC}$. The weakness of these magnetic effects and their similarities to those exhibited by $\mathrm{Mn}_{5} \mathrm{SiC}$ suggest that much of this behavior may be stemming from $\mathrm{Mn}_{5} \mathrm{SiC}$ impurities in the samples.

However, the measurements on the $\mathrm{Mn}_{16} \mathrm{SiC}_{4}$ and $\mathrm{Mn}_{17} \mathrm{Si}_{2} \mathrm{C}_{4}$-containing materials show some features that cannot be accounted for with the presence of $\mathrm{Mn}_{5} \mathrm{SiC}$ alone. For the $\mathrm{Mn}_{16} \mathrm{SiC}_{4}$-containing sample, the drop in magnetization at low temperatures relative to the peak is nearly $75 \%$ vs. $15 \%$ for $\mathrm{Mn}_{5} \mathrm{SiC}$. In addition, the field dependence at $20 \mathrm{~K}$ for this sample shows a meta-magnetic transition at ca. $0.1 \mathrm{~T}$. If these effects originate in the $\mathrm{Mn}_{16} \mathrm{SiC}_{4}$ phase, it would indicate that this phase has a stronger antiferromagnetic character in its low temperature ground state.

For the $\mathrm{Mn}_{17} \mathrm{Si}_{2} \mathrm{C}_{4}$ sample, the deviations from the trends exhibited by the $\mathrm{Mn}_{5} \mathrm{SiC}$ sample are more pronounced. In addition to the ferromagnetic jump below $\sim 290 \mathrm{~K}$, a second jump can be perceived at about $200 \mathrm{~K}$. After peaking just above $0.012 \mu_{\mathrm{B}} / \mathrm{Mn}$ atom, the magnetization drops as in the other samples. One interpretation of this data is that the first ferromagnetic ordering transition arises from a $\mathrm{Mn}_{5} \mathrm{SiC}$ impurity, while the second represents an intrinsic property of $\mathrm{Mn}_{17} \mathrm{Si}_{2} \mathrm{C}_{4}$. Another difference from the $\mathrm{Mn}_{5} \mathrm{SiC}$ sample is the appearance of a meta-magnetic transition in the low temperature hysteresis curve.

From these magnetic data, several conclusions can be drawn about the properties of $\mathrm{Mn}_{16} \mathrm{SiC}_{4}$ and $\mathrm{Mn}_{17} \mathrm{Si}_{2} \mathrm{C}_{4}$. Overall, their strength of magnetization is at least an order of magnitude lower than their neighbor in the Mn-Si-C system, $\mathrm{Mn}_{5} \mathrm{SiC}$. These gross features are also present in measurements on second set of samples containing $\mathrm{Mn}_{16} \mathrm{SiC}_{4}$ or $\mathrm{Mn}_{17} \mathrm{Si}_{2} \mathrm{C}_{4}$, but with lower yield (Figures S5 and S6). There are hints, however, of more subtle differences in Figure $\mathrm{S} 4$ which are not evident in the less pure samples: both $\mathrm{Mn}_{16} \mathrm{SiC}_{4}$ and $\mathrm{Mn}_{17} \mathrm{Si}_{2} \mathrm{C}_{4}$ show a larger down-turn in magnetization at lower temperatures, as well as meta-magnetic transitions under increasing fields at these temperatures.

As more phase-pure samples become available, it will be interesting to investigate these magnetic features in more detail, and perhaps connect the differences in ordering to differences in sizes and topologies of the $\mathrm{Mn}-\mathrm{Si}$ and $\mathrm{Mn}-\mathrm{C}$ domains within their structures. For now, however, we note that the magnetic moments in these phases are only small fractions of a Bohr magneton per $\mathrm{Mn}$ atom, and are unlikely to significantly influence the structural chemistry in this system. We can thus safely neglect in 
our theoretical work any magnetic ordering effects that might be involved in the stabilization of the TCPcarbide intergrowth features of these compounds.

(a)

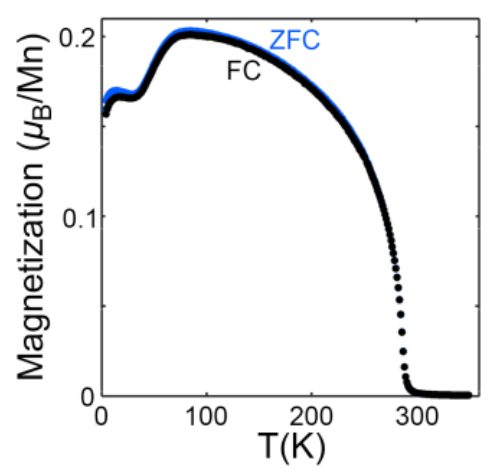

Major phase: $\mathrm{Mn}_{5} \mathrm{SiC}$

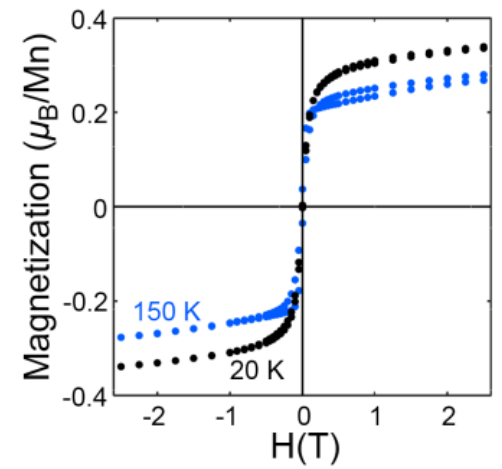

(b)

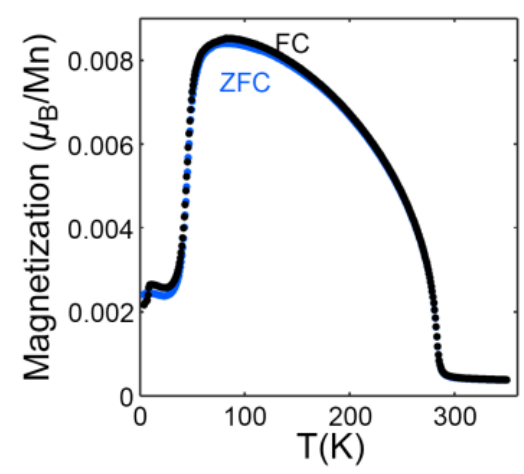

(c)

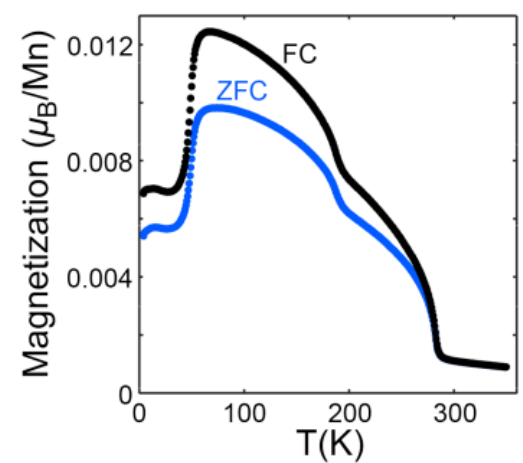

Major phase: $\mathrm{Mn}_{17} \mathrm{Si}_{2} \mathrm{C}_{4}$

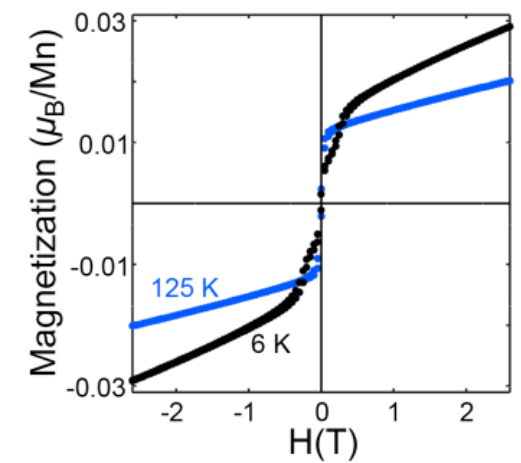

Figure S4. Magnetic properties of phases in the Mn-Si-C system. Plots of magnetization as a function of temperature (at a constant field of $1000 \mathrm{Oe}$ ) and applied field (at the temperatures indicated) are shown for samples in which the majority phase is (a) $\mathrm{Mn}_{5} \mathrm{SiC}$, (b) $\mathrm{Mn}_{16} \mathrm{SiC}_{4}$, or (c) $\mathrm{Mn}_{17} \mathrm{Si}_{2} \mathrm{C}_{4}$. Both the $\mathrm{Mn}_{16} \mathrm{SiC}_{4}$ and $\mathrm{Mn}_{17} \mathrm{Si}_{2} \mathrm{C}_{4}$ samples contain significant fractions of $\mathrm{Mn}_{5} \mathrm{SiC}$, which determines several of the major features observed. ZCF: zero field cooled. FC: field cooled. The magnetic moment/Mn atom values are calculated based on the nominal compositions of the samples. 

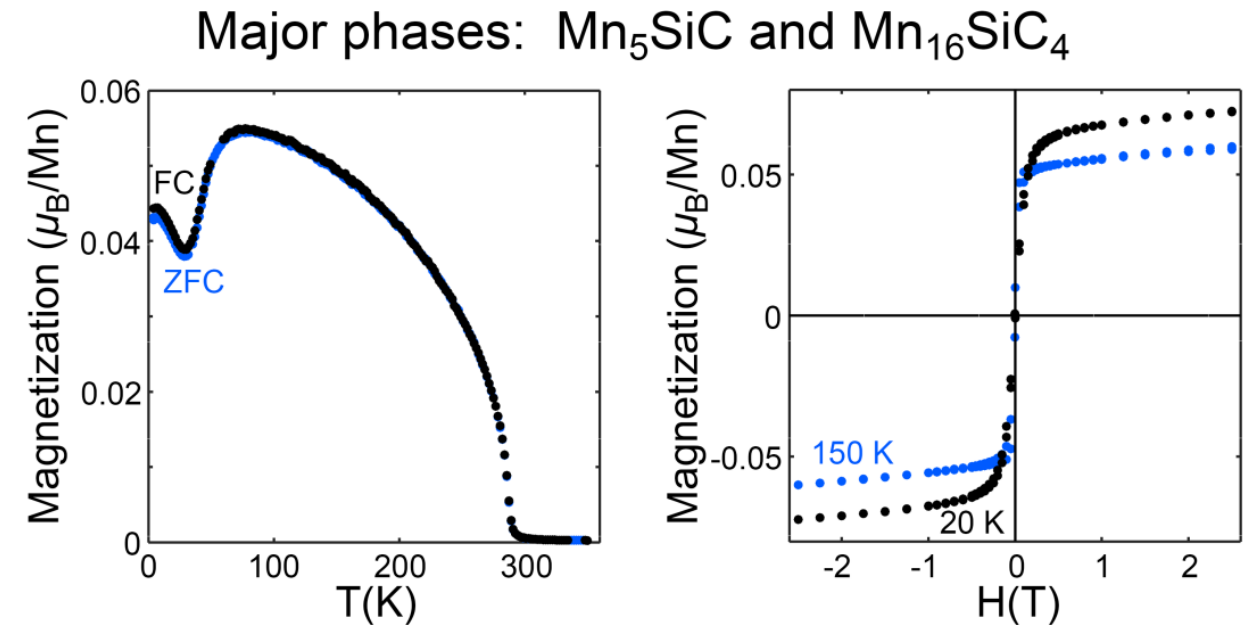

Figure S5. Magnetization data for a sample whose major phases are $\mathrm{Mn}_{5} \mathrm{SiC}$ and $\mathrm{Mn}_{16} \mathrm{SiC}_{4}$, according to powder X-ray diffraction measurements.

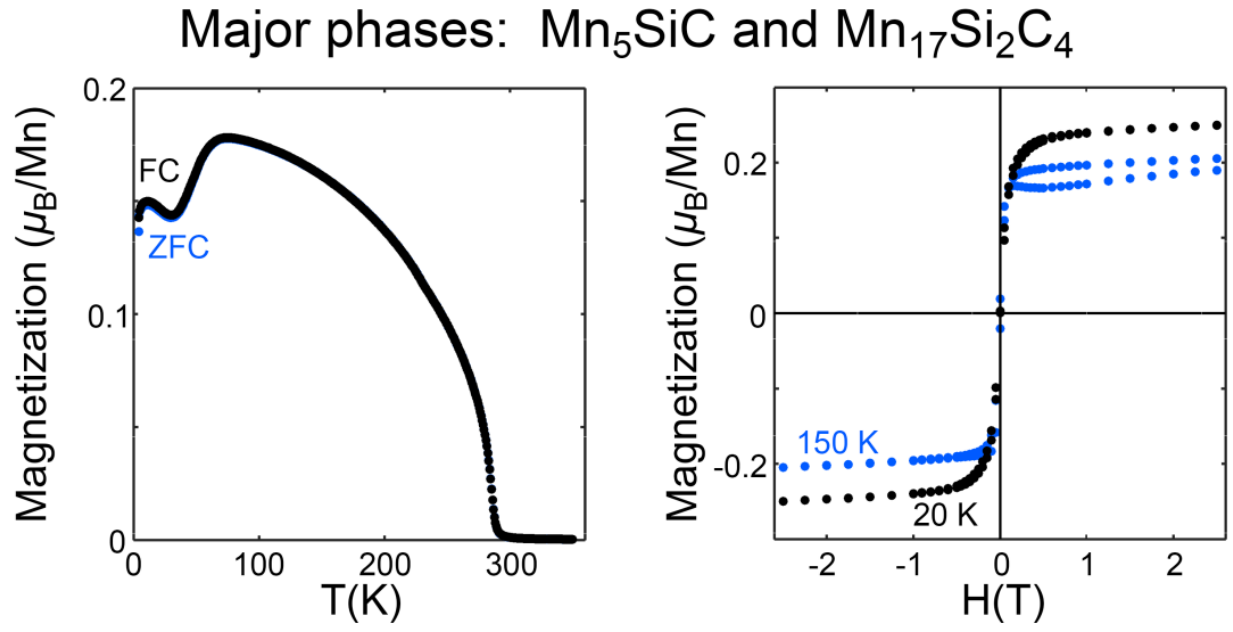

Figure S6. Magnetic properties measurements for a sample whose major phases are $\mathrm{Mn}_{5} \mathrm{SiC}$ and $\mathrm{Mn}_{17} \mathrm{Si}_{2} \mathrm{C}_{4}$ according to powder X-ray diffraction data. 


\section{S7. Computational details}

All electronic calculations (as listed in Table S8) are performed on primitive unit cells. In Tables S9-S11, all data are converted back to conventional unit cells when applicable for convenience.

Table S8. Energy cutoffs, k-point grids, and FFT grids used in the DFT calculations

\begin{tabular}{cccccc}
\hline \multirow{2}{*}{ Structure } & $\begin{array}{c}\text { VASP } \\
\text { k-point grid }\end{array}$ & $\begin{array}{c}\text { VASP energy } \\
\text { cutoff }(\mathrm{eV})\end{array}$ & $\begin{array}{c}\text { ABINIT } \\
\text { k-point grid }\end{array}$ & $\begin{array}{c}\text { ABINIT energy } \\
\text { cutoff (Hartree) }\end{array}$ & FFT grid \\
\hline $\mathrm{Mn}$ & $12 \times 12 \times 12$ & 500.0 & - & - & - \\
$\mathrm{Si}$ & $12 \times 12 \times 12$ & 500.0 & - & - & - \\
$\mathrm{Mn}{ }_{3} \mathrm{C}$ & $12 \times 12 \times 12$ & 500.0 & $6 \times 6 \times 6$ & 80 & $80 \times 100 \times 72$ \\
$\mathrm{Mn}_{3} \mathrm{Si}\left(\mathrm{BiF}_{3}\right)$ & $12 \times 12 \times 12$ & 500.0 & $6 \times 6 \times 6$ & 80 & $60 \times 60 \times 60$ \\
$\mathrm{Mn}_{3} \mathrm{Si}\left(\mathrm{Cr}_{3} \mathrm{Si}\right)$ & $12 \times 12 \times 12$ & 500.0 & $6 \times 6 \times 6$ & 80 & $72 \times 72 \times 72$ \\
$\mathrm{Mn}_{16} \mathrm{SiC}_{4}$ & $8 \times 10 \times 12$ & 500.0 & $6 \times 6 \times 6$ & 80 & $96 \times 96 \times 96$ \\
$\mathrm{Mn}_{17} \mathrm{Si}_{2} \mathrm{C}_{4}$ & $12 \times 10 \times 8$ & 500.0 & $3 \times 3 \times 3$ & 80 & $96 \times 120 \times 160$ \\
$\mathrm{Mn}_{5} \mathrm{SiC}$ & $10 \times 10 \times 10$ & 500.0 & $4 \times 4 \times 4$ & 80 & $96 \times 96 \times 120$ \\
\hline
\end{tabular}

Table S9. Total energies for the computationally optimized structures (Hartree/unit cell)

\begin{tabular}{ccc}
\hline Structure & VASP & abinit \\
\hline $\mathrm{Mn}$ & -21.68594 & - \\
$\mathrm{Si}$ & -1.75708 & - \\
$\mathrm{Mn}{ }_{3} \mathrm{C}$ & -6.05446 & -198.5107 \\
$\mathrm{Mn}_{3} \mathrm{Si}\left(\mathrm{BiF}_{3}\right)$ & -5.51029 & -191.6111 \\
$\mathrm{Mn}_{3} \mathrm{Si}\left(\mathrm{Cr}_{3} \mathrm{Si}\right)$ & -2.76600 & -95.8067 \\
$\mathrm{Mn}_{16} \mathrm{SiC}_{4}$ & -15.5639 & -522.0385 \\
$\mathrm{Mn}_{17} \mathrm{Si}_{2} \mathrm{C}_{4}$ & -16.8378 & -559.3297 \\
$\mathrm{Mn}_{5} \mathrm{SiC}$ & -10.0210 & -331.5389 \\
\hline
\end{tabular}

Table S10. Computationally optimized unit cell parameters

\begin{tabular}{ccccccc}
\hline Structure & $a(\AA)$ & $b(\AA)$ & $c(\AA)$ & $\boldsymbol{\alpha}\left(^{\circ}\right)$ & $\boldsymbol{\beta}\left(^{\circ}\right)$ & $\boldsymbol{\gamma}\left(^{\circ}\right)$ \\
\hline $\mathrm{Mn}$ & 8.3867 & 8.3867 & 8.3867 & 90 & 90 & 90 \\
$\mathrm{Si}$ & 5.3893 & 5.3893 & 5.3893 & 90 & 90 & 90 \\
$\mathrm{Mn}_{3} \mathrm{C}$ & 4.8561 & 6.5495 & 4.3725 & 90 & 90 & 90 \\
$\mathrm{Mn}_{3} \mathrm{Si}\left(\mathrm{BiF}_{3}\right)$ & 5.4760 & 5.4760 & 5.4760 & 90 & 90 & 90 \\
$\mathrm{Mn}_{3} \mathrm{Si}\left(\mathrm{Cr}_{3} \mathrm{Si}\right)$ & 4.3538 & 4.3538 & 4.3538 & 90 & 90 & 90
\end{tabular}




\begin{tabular}{ccccccc}
$\mathrm{Mn}_{16} \mathrm{SiC}_{4}$ & 9.9549 & 7.3084 & 6.1221 & 90 & 120.09 & 90 \\
$\mathrm{Mn}_{17} \mathrm{Si}_{2} \mathrm{C}_{4}$ & 6.0833 & 7.4131 & 9.9679 & 90 & 106.39 & 90 \\
$\mathrm{Mn}_{5} \mathrm{SiC}$ & 9.5327 & 7.7406 & 7.2970 & 90 & 90 & 90 \\
\hline
\end{tabular}

Table S1 1. Computationally optimized atomic coordinates

\begin{tabular}{|c|c|c|c|c|}
\hline Structure & Element & $x$ & $y$ & $z$ \\
\hline \multirow[t]{29}{*}{$\mathrm{Mn}$} & $\mathrm{Mn}$ & 0 & 0 & 0 \\
\hline & $\mathrm{Mn}$ & 0.5 & 0.5 & 0.5 \\
\hline & $\mathrm{Mn}$ & 0.31714 & 0.68286 & 0.68285 \\
\hline & $\mathrm{Mn}$ & 0.81714 & 0.18286 & 0.18285 \\
\hline & $\mathrm{Mn}$ & 0.31714 & 0.31714 & 0.31715 \\
\hline & $\mathrm{Mn}$ & 0.81714 & 0.81714 & 0.81715 \\
\hline & $\mathrm{Mn}$ & 0.68286 & 0.31714 & 0.68285 \\
\hline & $\mathrm{Mn}$ & 0.18286 & 0.81714 & 0.18285 \\
\hline & $\mathrm{Mn}$ & 0.68286 & 0.68286 & 0.31715 \\
\hline & $\mathrm{Mn}$ & 0.18286 & 0.18286 & 0.81715 \\
\hline & $\mathrm{Mn}$ & 0.35632 & 0.96289 & 0.64369 \\
\hline & $\mathrm{Mn}$ & 0.85632 & 0.46289 & 0.14369 \\
\hline & $\mathrm{Mn}$ & 0.35632 & 0.64368 & 0.96286 \\
\hline & $\mathrm{Mn}$ & 0.85632 & 0.14368 & 0.46286 \\
\hline & $\mathrm{Mn}$ & 0.64368 & 0.64368 & 0.03714 \\
\hline & $\mathrm{Mn}$ & 0.14368 & 0.14368 & 0.53714 \\
\hline & $\mathrm{Mn}$ & 0.64368 & 0.03711 & 0.64369 \\
\hline & $\mathrm{Mn}$ & 0.14368 & 0.53711 & 0.14369 \\
\hline & $\mathrm{Mn}$ & 0.64368 & 0.35632 & 0.96286 \\
\hline & $\mathrm{Mn}$ & 0.14368 & 0.85632 & 0.46286 \\
\hline & $\mathrm{Mn}$ & 0.35632 & 0.35632 & 0.03714 \\
\hline & Mn & 0.85632 & 0.85632 & 0.53714 \\
\hline & Mn & 0.03711 & 0.35632 & 0.35631 \\
\hline & $\mathrm{Mn}$ & 0.53711 & 0.85632 & 0.85631 \\
\hline & $\mathrm{Mn}$ & 0.53711 & 0.14368 & 0.14369 \\
\hline & $\mathrm{Mn}$ & 0.03711 & 0.64368 & 0.64369 \\
\hline & $\mathrm{Mn}$ & 0.14368 & 0.46289 & 0.85631 \\
\hline & Mn & 0.64368 & 0.96289 & 0.35631 \\
\hline & $\mathrm{Mn}$ & 0.46289 & 0.85632 & 0.14369 \\
\hline
\end{tabular}




\begin{tabular}{|c|c|c|c|c|}
\hline & $\mathrm{Mn}$ & 0.96289 & 0.35632 & 0.64369 \\
\hline & $\mathrm{Mn}$ & 0.85632 & 0.53711 & 0.85631 \\
\hline & $\mathrm{Mn}$ & 0.35632 & 0.03711 & 0.35631 \\
\hline & $\mathrm{Mn}$ & 0.46289 & 0.14368 & 0.85631 \\
\hline & $\mathrm{Mn}$ & 0.96289 & 0.64368 & 0.35631 \\
\hline & $\mathrm{Mn}$ & 0.78082 & 0.41223 & 0.41222 \\
\hline & $\mathrm{Mn}$ & 0.28082 & 0.91223 & 0.91222 \\
\hline & Mn & 0.58777 & 0.21918 & 0.41222 \\
\hline & $\mathrm{Mn}$ & 0.08777 & 0.71918 & 0.91222 \\
\hline & $\mathrm{Mn}$ & 0.21918 & 0.41223 & 0.58778 \\
\hline & $\mathrm{Mn}$ & 0.71918 & 0.91223 & 0.08778 \\
\hline & $\mathrm{Mn}$ & 0.58777 & 0.78082 & 0.58778 \\
\hline & $\mathrm{Mn}$ & 0.08777 & 0.28082 & 0.08778 \\
\hline & $\mathrm{Mn}$ & 0.21918 & 0.58777 & 0.41222 \\
\hline & $\mathrm{Mn}$ & 0.71918 & 0.08777 & 0.91222 \\
\hline & $\mathrm{Mn}$ & 0.78082 & 0.58777 & 0.58778 \\
\hline & $\mathrm{Mn}$ & 0.28082 & 0.08777 & 0.08778 \\
\hline & $\mathrm{Mn}$ & 0.41223 & 0.78082 & 0.41222 \\
\hline & $\mathrm{Mn}$ & 0.91223 & 0.28082 & 0.91222 \\
\hline & $\mathrm{Mn}$ & 0.41223 & 0.21918 & 0.58778 \\
\hline & $\mathrm{Mn}$ & 0.91223 & 0.71918 & 0.08778 \\
\hline & $\mathrm{Mn}$ & 0.58777 & 0.58777 & 0.78083 \\
\hline & $\mathrm{Mn}$ & 0.08777 & 0.08777 & 0.28083 \\
\hline & $\mathrm{Mn}$ & 0.41223 & 0.58777 & 0.21917 \\
\hline & $\mathrm{Mn}$ & 0.91223 & 0.08777 & 0.71917 \\
\hline & $\mathrm{Mn}$ & 0.41223 & 0.41223 & 0.78083 \\
\hline & $\mathrm{Mn}$ & 0.91223 & 0.91223 & 0.28083 \\
\hline & $\mathrm{Mn}$ & 0.58777 & 0.41223 & 0.21917 \\
\hline & $\mathrm{Mn}$ & 0.08777 & 0.91223 & 0.71917 \\
\hline \multirow[t]{6}{*}{$\mathrm{Si}$} & $\mathrm{Si}$ & 0 & 0 & 0 \\
\hline & $\mathrm{Si}$ & 0.25 & 0.25 & 0.25 \\
\hline & $\mathrm{Si}$ & 0 & 0.5 & 0.5 \\
\hline & $\mathrm{Si}$ & 0.25 & 0.75 & 0.75 \\
\hline & $\mathrm{Si}$ & 0.5 & 0 & 0.5 \\
\hline & $\mathrm{Si}$ & 0.75 & 0.25 & 0.75 \\
\hline
\end{tabular}




\begin{tabular}{|c|c|c|c|c|}
\hline & $\mathrm{Si}$ & 0.5 & 0.5 & 0 \\
\hline & $\mathrm{Si}$ & 0.75 & 0.75 & 0.25 \\
\hline \multirow[t]{16}{*}{$\mathrm{Mn}_{3} \mathrm{C}$} & $\mathrm{Mn}$ & 0.03023 & 0.25 & 0.65741 \\
\hline & $\mathrm{Mn}$ & 0.53023 & 0.25 & 0.84259 \\
\hline & $\mathrm{Mn}$ & 0.96977 & 0.75 & 0.34259 \\
\hline & $\mathrm{Mn}$ & 0.46977 & 0.75 & 0.15741 \\
\hline & $\mathrm{Mn}$ & 0.18626 & 0.06469 & 0.15541 \\
\hline & $\mathrm{Mn}$ & 0.68626 & 0.06469 & 0.34458 \\
\hline & $\mathrm{Mn}$ & 0.81374 & 0.93531 & 0.84459 \\
\hline & $\mathrm{Mn}$ & 0.31374 & 0.93531 & 0.65541 \\
\hline & $\mathrm{Mn}$ & 0.68626 & 0.43531 & 0.34458 \\
\hline & $\mathrm{Mn}$ & 0.31374 & 0.56469 & 0.65541 \\
\hline & $\mathrm{Mn}$ & 0.18626 & 0.43531 & 0.15541 \\
\hline & $\mathrm{Mn}$ & 0.81374 & 0.56469 & 0.84459 \\
\hline & $\mathrm{C}$ & 0.37761 & 0.25 & 0.43575 \\
\hline & $\mathrm{C}$ & 0.12239 & 0.75 & 0.93575 \\
\hline & $\mathrm{C}$ & 0.87761 & 0.25 & 0.06425 \\
\hline & $\mathrm{C}$ & 0.62239 & 0.75 & 0.56425 \\
\hline \multirow[t]{16}{*}{$\operatorname{Mn} 3 \mathrm{Si}\left(\mathrm{BiF}_{3}\right)$} & $\mathrm{Mn}$ & 0 & 0.5 & 0 \\
\hline & $\mathrm{Mn}$ & 0.5 & 0 & 0 \\
\hline & $\mathrm{Mn}$ & 0.5 & 0.5 & 0.5 \\
\hline & $\mathrm{Mn}$ & 0 & 0 & 0.5 \\
\hline & $\mathrm{Mn}$ & 0.25 & 0.25 & 0.25 \\
\hline & $\mathrm{Mn}$ & 0.25 & 0.75 & 0.75 \\
\hline & $\mathrm{Mn}$ & 0.75 & 0.25 & 0.75 \\
\hline & $\mathrm{Mn}$ & 0.75 & 0.75 & 0.25 \\
\hline & $\mathrm{Mn}$ & 0.25 & 0.75 & 0.25 \\
\hline & $\mathrm{Mn}$ & 0.75 & 0.75 & 0.75 \\
\hline & $\mathrm{Mn}$ & 0.25 & 0.25 & 0.75 \\
\hline & $\mathrm{Mn}$ & 0.75 & 0.25 & 0.25 \\
\hline & $\mathrm{Si}$ & 0 & 0 & 0 \\
\hline & $\mathrm{Si}$ & 0.5 & 0 & 0.5 \\
\hline & $\mathrm{Si}$ & 0 & 0.5 & 0.5 \\
\hline & $\mathrm{Si}$ & 0.5 & 0.5 & 0 \\
\hline $\mathrm{Mn}_{3} \mathrm{Si}\left(\mathrm{Cr}_{3} \mathrm{Si}\right)$ & $\mathrm{Mn}$ & 0.75 & 0 & 0.5 \\
\hline
\end{tabular}




\begin{tabular}{|c|c|c|c|c|}
\hline & $\mathrm{Mn}$ & 0 & 0.5 & 0.75 \\
\hline & $\mathrm{Mn}$ & 0 & 0.5 & 0.25 \\
\hline & $\mathrm{Mn}$ & 0.5 & 0.75 & 0 \\
\hline & $\mathrm{Mn}$ & 0.25 & 0 & 0.5 \\
\hline & $\mathrm{Mn}$ & 0.5 & 0.25 & 0 \\
\hline & $\mathrm{Si}$ & 0 & 0 & 0 \\
\hline & $\mathrm{Si}$ & 0.5 & 0.5 & 0.5 \\
\hline \multirow[t]{28}{*}{$\mathrm{Mn}_{16} \mathrm{SiC}_{4}$} & $\mathrm{Mn}$ & 0.61041 & 0 & 0.25365 \\
\hline & $\mathrm{Mn}$ & 0.88959 & 0.5 & 0.74635 \\
\hline & $\mathrm{Mn}$ & 0.38959 & 0 & 0.74635 \\
\hline & $\mathrm{Mn}$ & 0.11041 & 0.5 & 0.25365 \\
\hline & $\mathrm{Mn}$ & 0.22144 & 0.5 & 0.79055 \\
\hline & $\mathrm{Mn}$ & 0.72144 & 0 & 0.79055 \\
\hline & $\mathrm{Mn}$ & 0.27856 & 0 & 0.20945 \\
\hline & $\mathrm{Mn}$ & 0.77856 & 0.5 & 0.20945 \\
\hline & $\mathrm{Mn}$ & 0.37903 & 0.5 & 0.28285 \\
\hline & $\mathrm{Mn}$ & 0.12097 & 0 & 0.71715 \\
\hline & $\mathrm{Mn}$ & 0.62097 & 0.5 & 0.71715 \\
\hline & $\mathrm{Mn}$ & 0.87903 & 0 & 0.28285 \\
\hline & $\mathrm{Mn}$ & 0.5 & 0.15741 & 0.5 \\
\hline & $\mathrm{Mn}$ & 0.5 & 0.84259 & 0.5 \\
\hline & $\mathrm{Mn}$ & 0 & 0.65741 & 0.5 \\
\hline & $\mathrm{Mn}$ & 0 & 0.34259 & 0.5 \\
\hline & $\mathrm{Mn}$ & 0.35901 & 0.33698 & 0.6276 \\
\hline & $\mathrm{Mn}$ & 0.35901 & 0.66302 & 0.6276 \\
\hline & $\mathrm{Mn}$ & 0.85901 & 0.16302 & 0.6276 \\
\hline & $\mathrm{Mn}$ & 0.64099 & 0.66302 & 0.3724 \\
\hline & $\mathrm{Mn}$ & 0.14099 & 0.16302 & 0.3724 \\
\hline & $\mathrm{Mn}$ & 0.64099 & 0.33698 & 0.3724 \\
\hline & $\mathrm{Mn}$ & 0.85901 & 0.83698 & 0.6276 \\
\hline & $\mathrm{Mn}$ & 0.14099 & 0.83698 & 0.3724 \\
\hline & $\mathrm{Mn}$ & 0.38922 & 0.2146 & 0.05214 \\
\hline & $\mathrm{Mn}$ & 0.11078 & 0.7146 & 0.94785 \\
\hline & $\mathrm{Mn}$ & 0.61078 & 0.2146 & 0.94785 \\
\hline & $\mathrm{Mn}$ & 0.11078 & 0.2854 & 0.94785 \\
\hline
\end{tabular}




\begin{tabular}{|c|c|c|c|c|}
\hline & $\mathrm{Mn}$ & 0.61078 & 0.7854 & 0.94785 \\
\hline & $\mathrm{Mn}$ & 0.88922 & 0.2854 & 0.05214 \\
\hline & $\mathrm{Mn}$ & 0.88922 & 0.7146 & 0.05214 \\
\hline & $\mathrm{Mn}$ & 0.38922 & 0.7854 & 0.05214 \\
\hline & $\mathrm{Si}$ & 0.5 & 0.5 & 0 \\
\hline & $\mathrm{Si}$ & 0 & 0 & 0 \\
\hline & $\mathrm{C}$ & 0.29114 & 0.26489 & 0.2818 \\
\hline & $\mathrm{C}$ & 0.20886 & 0.76489 & 0.7182 \\
\hline & $\mathrm{C}$ & 0.70886 & 0.26489 & 0.7182 \\
\hline & $\mathrm{C}$ & 0.20886 & 0.23511 & 0.7182 \\
\hline & $\mathrm{C}$ & 0.70886 & 0.73511 & 0.7182 \\
\hline & $\mathrm{C}$ & 0.79114 & 0.23511 & 0.2818 \\
\hline & $\mathrm{C}$ & 0.29114 & 0.73511 & 0.2818 \\
\hline & $\mathrm{C}$ & 0.79114 & 0.76489 & 0.2818 \\
\hline \multirow[t]{21}{*}{$\mathrm{Mn}_{17} \mathrm{Si}_{2} \mathrm{C}_{4}$} & $\mathrm{Mn}$ & 0.47333 & 0.25 & 0.64596 \\
\hline & $\mathrm{Mn}$ & 0.52667 & 0.75 & 0.35404 \\
\hline & $\mathrm{Mn}$ & 0.5058 & 0.08923 & 0.40533 \\
\hline & $\mathrm{Mn}$ & 0.4942 & 0.58923 & 0.59467 \\
\hline & $\mathrm{Mn}$ & 0.4942 & 0.91077 & 0.59467 \\
\hline & $\mathrm{Mn}$ & 0.5058 & 0.41077 & 0.40533 \\
\hline & $\mathrm{Mn}$ & 0.81097 & 0.55182 & 0.0103 \\
\hline & $\mathrm{Mn}$ & 0.18903 & 0.44818 & 0.9897 \\
\hline & $\mathrm{Mn}$ & 0.81097 & 0.94818 & 0.0103 \\
\hline & $\mathrm{Mn}$ & 0.18903 & 0.05182 & 0.9897 \\
\hline & $\mathrm{Mn}$ & 0.04675 & 0.75 & 0.87446 \\
\hline & $\mathrm{Mn}$ & 0.95325 & 0.25 & 0.12554 \\
\hline & $\mathrm{Mn}$ & 0.84094 & 0.4809 & 0.74907 \\
\hline & $\mathrm{Mn}$ & 0.15906 & 0.5191 & 0.25093 \\
\hline & $\mathrm{Mn}$ & 0.84094 & 0.0191 & 0.74907 \\
\hline & $\mathrm{Mn}$ & 0.15906 & 0.9809 & 0.25093 \\
\hline & $\mathrm{Mn}$ & 0.86713 & 0.97528 & 0.387 \\
\hline & $\mathrm{Mn}$ & 0.86713 & 0.52472 & 0.387 \\
\hline & $\mathrm{Mn}$ & 0.13287 & 0.02472 & 0.613 \\
\hline & $\mathrm{Mn}$ & 0.13287 & 0.47528 & 0.613 \\
\hline & $\mathrm{Mn}$ & 0.15424 & 0.75 & 0.44448 \\
\hline
\end{tabular}




\begin{tabular}{|c|c|c|c|c|}
\hline & $\mathrm{Mn}$ & 0.84576 & 0.25 & 0.55552 \\
\hline & $\mathrm{Mn}$ & 0.8642 & 0.75 & 0.58682 \\
\hline & $\mathrm{Mn}$ & 0.1358 & 0.25 & 0.41318 \\
\hline & $\mathrm{Mn}$ & 0.26398 & 0.75 & 0.71904 \\
\hline & $\mathrm{Mn}$ & 0.73602 & 0.25 & 0.28096 \\
\hline & $\mathrm{Mn}$ & 0.45813 & 0.75 & 0.98433 \\
\hline & $\mathrm{Mn}$ & 0.54187 & 0.25 & 0.01567 \\
\hline & $\mathrm{Mn}$ & 0.17102 & 0.25 & 0.78444 \\
\hline & $\mathrm{Mn}$ & 0.82898 & 0.75 & 0.21556 \\
\hline & $\mathrm{Mn}$ & 0.52112 & 0.53748 & 0.17101 \\
\hline & $\mathrm{Mn}$ & 0.52112 & 0.96252 & 0.17101 \\
\hline & $\mathrm{Mn}$ & 0.47888 & 0.03748 & 0.82899 \\
\hline & $\mathrm{Mn}$ & 0.47888 & 0.46252 & 0.82899 \\
\hline & $\mathrm{Si}$ & 0.18463 & 0.75 & 0.10994 \\
\hline & $\mathrm{Si}$ & 0.81537 & 0.25 & 0.89006 \\
\hline & $\mathrm{Si}$ & 0.33783 & 0.25 & 0.19033 \\
\hline & $\mathrm{Si}$ & 0.66217 & 0.75 & 0.80967 \\
\hline & $\mathrm{C}$ & 0.23431 & 0.00372 & 0.44949 \\
\hline & $\mathrm{C}$ & 0.23431 & 0.49628 & 0.44949 \\
\hline & $\mathrm{C}$ & 0.76569 & -0.00372 & 0.55051 \\
\hline & $\mathrm{C}$ & 0.76569 & 0.50372 & 0.55051 \\
\hline & $\mathrm{C}$ & 0.16821 & 0.53546 & 0.80872 \\
\hline & $\mathrm{C}$ & 0.83179 & 0.03546 & 0.19128 \\
\hline & $\mathrm{C}$ & 0.83179 & 0.46454 & 0.19128 \\
\hline & $\mathrm{C}$ & 0.16821 & 0.96454 & 0.80872 \\
\hline \multirow[t]{10}{*}{$\mathrm{Mn}_{5} \mathrm{SiC}$} & $\mathrm{Mn}$ & 0.3587 & 0.15625 & 0.87062 \\
\hline & $\mathrm{Mn}$ & 0.8587 & 0.65625 & 0.87062 \\
\hline & $\mathrm{Mn}$ & 0.6413 & 0.84375 & 0.37062 \\
\hline & $\mathrm{Mn}$ & 0.1413 & 0.34375 & 0.37062 \\
\hline & $\mathrm{Mn}$ & 0.6413 & 0.15625 & 0.87062 \\
\hline & $\mathrm{Mn}$ & 0.1413 & 0.65625 & 0.87062 \\
\hline & $\mathrm{Mn}$ & 0.3587 & 0.84375 & 0.37062 \\
\hline & $\mathrm{Mn}$ & 0.8587 & 0.34375 & 0.37062 \\
\hline & $\mathrm{Mn}$ & 0 & 0.5556 & 0.18865 \\
\hline & $\mathrm{Mn}$ & 0.5 & 0.9444 & 0.68865 \\
\hline
\end{tabular}




\begin{tabular}{|c|c|c|c|}
\hline $\mathrm{Mn}$ & 0 & 0.4444 & 0.68865 \\
\hline $\mathrm{Mn}$ & 0.5 & 0.0556 & 0.18865 \\
\hline $\mathrm{Mn}$ & 0.5 & 0.3775 & 0.68867 \\
\hline $\mathrm{Mn}$ & 0 & 0.8775 & 0.68867 \\
\hline $\mathrm{Mn}$ & 0.5 & 0.6225 & 0.18868 \\
\hline $\mathrm{Mn}$ & 0 & 0.1225 & 0.18868 \\
\hline $\mathrm{Mn}$ & 0.6297 & 0.5 & 0.93867 \\
\hline $\mathrm{Mn}$ & 0.8703 & 0 & 0.43867 \\
\hline $\mathrm{Mn}$ & 0.3703 & 0.5 & 0.43867 \\
\hline $\mathrm{Mn}$ & 0.8703 & 0 & 0.93867 \\
\hline $\mathrm{Mn}$ & 0.3703 & 0.5 & 0.93867 \\
\hline $\mathrm{Mn}$ & 0.1297 & 0 & 0.43867 \\
\hline $\mathrm{Mn}$ & 0.6297 & 0.5 & 0.43867 \\
\hline $\mathrm{Mn}$ & 0.1297 & 0 & 0.93867 \\
\hline $\mathrm{Mn}$ & 0.12219 & 0.1734 & 0.68868 \\
\hline $\mathrm{Mn}$ & 0.37781 & 0.3266 & 0.18868 \\
\hline $\mathrm{Mn}$ & 0.87781 & 0.8266 & 0.18868 \\
\hline $\mathrm{Mn}$ & 0.37781 & 0.6734 & 0.68868 \\
\hline $\mathrm{Mn}$ & 0.87781 & 0.1734 & 0.68868 \\
\hline $\mathrm{Mn}$ & 0.62219 & 0.3266 & 0.18868 \\
\hline $\mathrm{Mn}$ & 0.12219 & 0.8266 & 0.18868 \\
\hline $\mathrm{Mn}$ & 0.62219 & 0.6734 & 0.68868 \\
\hline $\mathrm{Mn}$ & 0.6413 & 0.84369 & 0.00672 \\
\hline $\mathrm{Mn}$ & 0.1413 & 0.34369 & 0.00672 \\
\hline $\mathrm{Mn}$ & 0.3587 & 0.15631 & 0.50672 \\
\hline $\mathrm{Mn}$ & 0.8587 & 0.65631 & 0.50672 \\
\hline $\mathrm{Mn}$ & 0.3587 & 0.84369 & 0.00672 \\
\hline $\mathrm{Mn}$ & 0.8587 & 0.34369 & 0.00672 \\
\hline $\mathrm{Mn}$ & 0.6413 & 0.15631 & 0.50672 \\
\hline $\mathrm{Mn}$ & 0.1413 & 0.65631 & 0.50672 \\
\hline $\mathrm{Si}$ & 0.24384 & 0.41528 & 0.68867 \\
\hline $\mathrm{Si}$ & 0.25616 & 0.08472 & 0.18867 \\
\hline $\mathrm{Si}$ & 0.75616 & 0.58472 & 0.18867 \\
\hline $\mathrm{Si}$ & 0.25616 & 0.91528 & 0.68867 \\
\hline $\mathrm{Si}$ & 0.75616 & 0.41528 & 0.68867 \\
\hline
\end{tabular}




$\begin{array}{lccc}\mathrm{Si} & 0.74384 & 0.08472 & 0.18867 \\ \mathrm{Si} & 0.24384 & 0.58472 & 0.18867 \\ \mathrm{Si} & 0.74384 & 0.91528 & 0.68867 \\ \mathrm{C} & 0 & 0.19702 & 0.4696 \\ \mathrm{C} & 0.5 & 0.30298 & 0.9696 \\ \mathrm{C} & 0 & 0.80298 & 0.9696 \\ \mathrm{C} & 0.5 & 0.69702 & 0.4696 \\ \mathrm{C} & 0.5 & 0.30304 & 0.40775 \\ \mathrm{C} & 0 & 0.80304 & 0.40775 \\ \mathrm{C} & 0.5 & 0.69696 & 0.90775 \\ \mathrm{C} & 0 & 0.19696 & 0.90775\end{array}$

\section{S8. DFT energies of formation for Mn-Si-C ternary phases}

Table S12. LDA-DFT energies for reaction involving the formation of Mn-Si-C ternary phases from simpler components

\begin{tabular}{ccc}
\hline Reaction & $\Delta \mathrm{E}(\mathrm{eV} /$ atom $)$ & $\Delta \mathrm{E}(\mathrm{kcal} /(\mathrm{mol} \cdot$ atom $))$ \\
\hline $\mathrm{Mn}_{3} \mathrm{Si}\left(\mathrm{BiF}_{3}\right)+4 \mathrm{Mn}_{3} \mathrm{C}+\mathrm{Mn} \rightarrow \mathrm{Mn}_{16} \mathrm{SiC}_{4}$ & 0.0311 & 0.7168 \\
$\mathrm{Mn}_{3} \mathrm{Si}\left(\mathrm{Cr}_{3} \mathrm{Si}\right)+4 \mathrm{Mn}_{3} \mathrm{C}+\mathrm{Mn} \rightarrow \mathrm{Mn}_{16} \mathrm{SiC}_{4}$ & 0.0381 & 0.8789 \\
$\frac{5}{3} \mathrm{Mn}_{3} \mathrm{Si}\left(\mathrm{BiF}_{3}\right)+4 \mathrm{Mn}_{3} \mathrm{C}+\frac{1}{3} \mathrm{Si} \rightarrow \mathrm{Mn}_{17} \mathrm{Si}_{2} \mathrm{C}_{4}$ & 0.0056 & 0.1290 \\
$\frac{5}{3} \mathrm{Mn}_{3} \mathrm{Si}\left(\mathrm{Cr}_{3} \mathrm{Si}\right)+4 \mathrm{Mn}_{3} \mathrm{C}+\frac{1}{3} \mathrm{Si} \rightarrow \mathrm{Mn}_{17} \mathrm{Si}_{2} \mathrm{C}_{4}$ & 0.0163 & 0.3757 \\
$\left.\frac{2}{3} \mathrm{Mn}_{3} \mathrm{Si}_{(\mathrm{BiF}}\right)+\mathrm{Mn}_{3} \mathrm{C}+\frac{1}{3} \mathrm{Si} \rightarrow \mathrm{Mn}_{5} \mathrm{SiC}$ & -0.0002 & -0.0044 \\
$\frac{2}{3} \mathrm{Mn}_{3} \mathrm{Si}\left(\mathrm{Cr}_{3} \mathrm{Si}\right)+\mathrm{Mn}_{3} \mathrm{C}+\frac{1}{3} \mathrm{Si} \rightarrow \mathrm{Mn}_{5} \mathrm{SiC}$ & 0.0139 & 0.3199 \\
\hline
\end{tabular}

\section{S9. Chemical Pressure analysis of $\mathrm{BiF}_{3}$-type $\mathrm{Mn}_{3} \mathrm{Si}$}

According to the $\mathrm{Mn}$-Si phase diagram, $\mathrm{Mn}_{3} \mathrm{Si}$ adopts the $\mathrm{BiF}_{3}$ structure type at high temperature (above $677^{\circ} \mathrm{C}$ ), which is a binary variant of bcc supercell. The structure of $\mathrm{BiF}_{3}$-type $\mathrm{Mn}_{3} \mathrm{Si}$ is shown in Figure $\mathrm{S} 7 \mathrm{a}$, where the rhombic dodecahedral coordination environment of one Si atom is highlighted.

The results of CP analysis on this structure are summarized in Figure S7b. The primary features to be observed are similar to the $\mathrm{Cr}_{3} \mathrm{Si}$ type $\mathrm{Mn}_{3} \mathrm{Si}$ : the $\mathrm{Si}$ atoms experience large negative $\mathrm{CP}$, indicating that they are too small for their coordination environments, while positive pressure lobes are found along the 
short Mn-Mn contacts, suggesting that the Mn framework would like to expand, but is held back by the desire for shorter Mn-Si distances (as well as some Mn-Mn distances). Although individually the Mn$\mathrm{Mn}$ positive CP lobes are significantly smaller than in the $\mathrm{Cr}_{3} \mathrm{Si}$ type, each $\mathrm{Mn}$ atom here mas more of them: 4 and 8 for the two symmetry distinct $\mathrm{Mn}$ sites compared to only 2 for $\mathrm{Mn}$ in the $\mathrm{Cr}_{3} \mathrm{Si}$. This higher multiplicity leads to the overall net pressures on the $\mathrm{Mn}$ atoms in the two structures being much more similar than would be expected by comparison of Figure S7b with Figure 2 of the main text. The net pressure magnitudes are, however, calculated to be higher for $\mathrm{Mn}_{3} \mathrm{Si}$ in the $\mathrm{Cr}_{3} \mathrm{Si}$ type than in the $\mathrm{BiF}_{3}$ type.
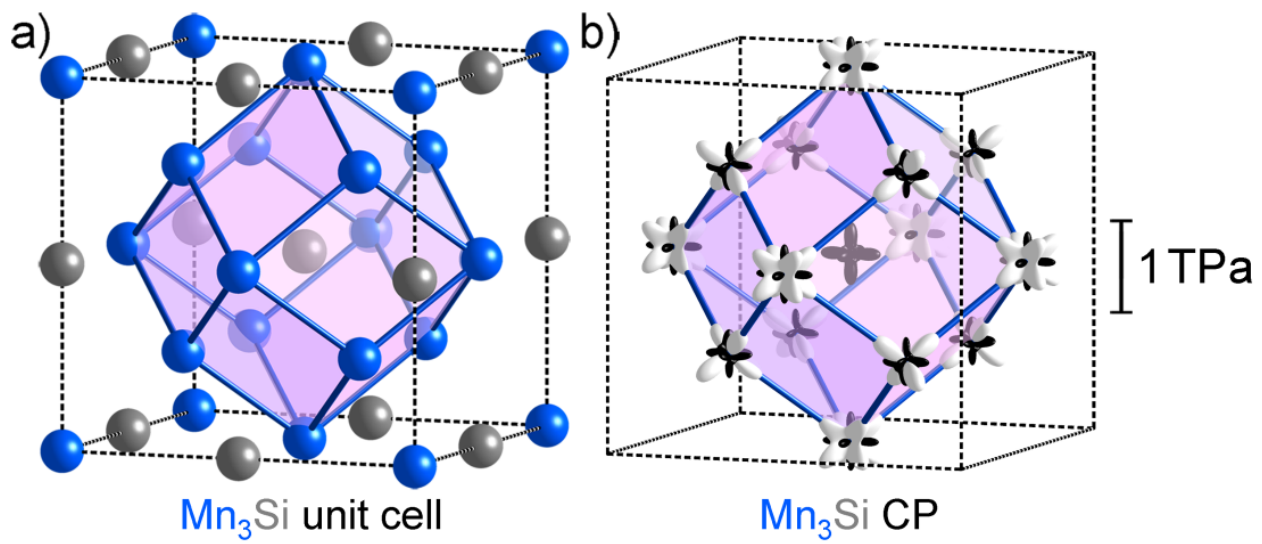

Figure S7. CP analysis of the $\mathrm{BiF}_{3}$-type high temperature polymorph of $\mathrm{Mn}_{3} \mathrm{Si}$. (a) The cubic unit cell of the phase, with the coordination polyhedron of the central Si atom highlighted. (b) DFT-CP anisotropy surfaces for the $\mathrm{Si} @ \mathrm{Mn}_{14}$ coordination polyhedron. The central Si atom experiences large negative pressures, while positive pressure lobes are found along the nearest neighbor Mn-Mn contacts defining the edges of the polyhedron.

\section{References}

(1) Butylenko, A. K.; Ignat'eva, I. Y., Mn-C Phase Diagram, ASM Alloy Phase Diagrams Database, Villars, P., editor-in-chief; Okamoto, H., Cenzual, K., section editors; http://www1.asminternational.org/asmenterprise/apd; ASM International, Materials Park, OH, 2006; last accessed 12/3/2015.

(2) Chen, Q. Acta Metall. Sin. (Eng. Ed.), Ser. B 1989, 2, 210-212.

(3) Okamoto, H., Mn-O Phase Diagram, ASM Alloy Phase Diagrams Database, Villars, P., editor-inchief; Okamoto, H., Cenzual, $\quad$ K., $\quad$ section editors; http://www1.asminternational.org/asmenterprise/apd; ASM International, Materials Park, OH, 2006; last accessed 12/1/2015.

(4) (a) Bergerhoff, G.; Hundt, R.; Sievers, R.; Brown, I. D. J. Chem. Inf. Comput. Sci. 1983, 23, 66-69; (b) Bergerhoff, G.; Brown, I. D. In Crystallographic Databases; Allen, F. H., Bergerhoff, Sievers, R., Eds.; International Union of Crystallography: Chester, 1987, p 77-95; (c) Belsky, A.; Hellenbrandt, M.; Karen, V. L.; Luksch, P. Acta Crystallogr. B 2002, 58, 364-369.

(5) Spinat, P.; Herpin, P. Bull. Soc. Fr. Mineral. Cristallogr. 1976, 99, 13-20. 